Cuadernos de Trabajo Social

ISSN: 1988-8295

\title{
Antunes, R. (eds). (2020). Uberização, Trabalho Digital e Indústria 4.0. [Uberization, Digital Work and Industry 4.0]. 1. Ed. São Paulo: Boitempo
}

In the first chapter, Ricardo Antunes provides an analysis of Intermittent Work and work uberization in Industry 4.0. The core argument is that "outsourcing, informality, and flexibility have become intrinsic parts of the lexicon and pragmatics in global corporate enterprise" (p. 11). Such aspect emphasizes the zero hour contract, leading to the accentuation of the bewilderment between daily time at work and the cycle outside of it. By becoming a self-exploiting proletarian of himself, the worker consents to a perverse condition of digital slavery.

Jamie Woodcock exposes Deliveroo's algorithmic panopticon: measurement, precarity, and illusion of control. The author highlights the job insecurity by the "autonomous independent contractors" associated with this food delivery app. The key mechanism of control for Woodcock lies in a subtly coercive management focused on the measurement of work processes. By associating the concept of "algorithmic panopticon" (by Miran Božovič) with Deliveroo, it warns about the unaccountability of the platform in relation to the worker and the use of data (whether from drivers or even customers).

In Digital Work, Mark Graham and Mohammad Amir Anwar scrutinize the semantic cores of the concept in a historical-geographical systematization. Unlike the first wave of digital work, digital work platforms create an oversupply of work in digital media, reducing labor costs and limiting bargaining power. Questioning who owns the digital space, the authors involve the perspective of collaborative networks.

Digital platforms, uberization of work and regulation in contemporary capitalism, written by Vitor Filgueiras and Ricardo Antunes, highlights the denial of salaried work, the exposure of subjects to unfair conditions and the non-regularization of digital platforms as precedents to the precarity of work. The authors highlight distinct perspectives that emphasize the bias about the discourse of a "new goodbye to the working class," alluding to the end of the centrality of work theses in the 1990s.

Clarissa Ribeiro Schinestsck develops The working conditions in digital platforms under the prism of environmental regulation on labor. The chapter emphasizes that the platforms' data collection produces forms of control over both workers and consumers. About the organization of work via applications, it underscores control by programming, management by numbers or rewards, constant availability of workers, automation of the labor market, etc. To put it more simply, the pressure of fear, exhausting workdays and capture of subjectivity cause total precariousness of work.

In the chapter on the Plataformization of work: characteristics and alternatives, Rafael Grohmann attributes to platforms the character of means of communication and of production, concomitantly. Being an instrument of capitalism, the algorithmic management of work generates a distancing by an idea of "neutrality", which allows the operationalization of other forms of control. Finally, the author lists attempts to regulate digital labor and collective organization movements.

Uberization: management and control of the just-in-time worker was written by Ludmila Costhek Abílio. Uberization signals "reduction of the worker to a factor of production that must be used in the exact measure of demands of capital" (p. 112). The chapter points out the transfer of labor control from the company to the worker, stressing how platforms encourage a multitude of autonomous workers under the title of partners but for exploitative purposes that may reflect in protests.

Marco Gonsales discusses Industry 4.0: platform companies, consent and resistance. The "digital bureaucracies" control labor rules and establish "platform companies that expand the capacity to organize and control labor and, therefore, to produce surplus value" (p. 128). Despite aspects that hinder class consciousness, workers were still able to benefit from technologies to organize protests, as in the Covid-19 pandemic where they went from "invisible to heroes."

A new productive restructuring after the 2008 crisis? Is the title of the chapter by Iuri Tonelo. Overcoming the limits of the rigidity of previous models, the flexibilization of labor markets, production, processes and consumption is distinguished from Fordism and Taylorism, which aimed to reduce working time. The austerity plan, increase in xenophobia, and the use of new technologies with "platform economy" are perceived as conditions imposed by the international economic crisis.

Ricardo Festi presents Critical contributions about labour sociology and automation. It presents the strand of the sociology of labor that believed that industrial automation would reach a process of autonomy and the preposition that industry would transform part of the workers into "new craftsmen. Given the impossibility of the demands for employment and profit converging in a healthy way, the platform economy reproduces tra- 
ditional aspects of capitalism under the "guise" of new nomenclatures, achieving greater, more effective and more precise control.

A new farewell to the working class? This is the debate launched by Vitor Filgueiras and Sávio Cavalcante about the argument that automation could conceal invisible or extinguish human labor in material production. According to the authors, public policies and income distribution may be important, but formal and legal labor bonds are crucial. To put it another way, deprived of labor rights, easily dismissed, inhibited from contesting actions and enveloped in an illusory atmosphere of being one's own boss, workers are subjected to precarity.

Luci Praun and Ricardo Antunes discuss The dismantling of labor rights in the era of informational-digital capitalism in chapter twelve. The influence of neoliberalism on the "extended and multiform precarity" of labor, the growth of unpaid work, and the urge for unpaid female labor as a cornerstone for market demands' operation are addressed, along with contemporary labor reforms that weaken union organization.

Industry 4.0 in the automotive chain: Mercedes-Benz in São Bernardo do Campo, is the chapter by Geraldo Augusto Pinto. It presents an overview of the automotive sector in Brazil, going through its establishment, growth, oligopolization, and transnationalization over the years. Notably, this diversification correlates the automotive industry to many economic sectors, receiving low protection barriers, financial support or tax support from the State. The car manufacturers compete aggressively, trying to avoid taxes and union organizations, approaching low-cost access to labor and natural resources.

Digital work and education in Brazil, is the theme incited by Fabiane Santana Previtali and Cílon César Fagiani. The demand for technological training parallel to other training does not coincide with a wage increase, creating a unilateral relationship between capital and proletariat. Furthermore, the difficulty in establishing a feeling of belonging to this class makes it difficult to form trade unions. It continuously reduces the work process autonomy, as Industry 4.0 imposes instructions for teaching practice, increasing the surveillance of teachers.

As the banking sector is part of an advanced portion in flexible capitalism, Arnaldo Mazzei Nogueira emphasizes Digital work in banks. With the increase of digital interaction, banks profit more and close more job vacancies, reducing wage and increasing turnover and intensity of working hours. Today, the banking profession is made up of "empowered" young people and "there is manipulation to convince them that they are no longer contract workers, but part of the corporation" (p. 246).

Claudia Mazzei Nogueira wrote about The health of telemarketing workers and online work. The telemarketing routine has a hectic pace, absence of breaks, exhausting productivity goals, repetitive movements, constant pressure, inadequate furniture and equipment, etc. This suggests that, operators develop health problems, whether physical or psychological. The organizations harshness can generate disturbances, "altering the full use of their capacities, and even leading them to 'automate' their thinking" (p. 251).

Walmartization of work: the cruel face of the technologies used in hypermarkets, is Patrícia Rocha Lemos' chapter theme. The large retail chains establish conditions with consumers that smaller companies do not reach, affecting the value chain. The concept of "walmartization" explains how companies reach added to technological innovations seek to destroy the regulatory policies of the New Deal. With system generating sales targets being, impersonality rules, causing dismissals, humiliation, and pressure in the work environment.

The strike at Vale: transnationalization and labor exploitation in Canada, by Thiago Trindade Aguiar, uses field research to delimit corporate strategies under the focus of global production networks. In 2006, the Canadian Inco was bought by Vale and started to hire temporary workers, watch and punish union activists, etc. The aftermath of this was the largest private sector strike in Canada in 30 years, marking a period of resistance by workers who suffered layoffs, harassment, and episodes of intimidation to their families.

Lastly, Isabel Roque covers Cyberactivism and unionism in Portuguese call centers. The increase in services has worsened workers' financial instability and reduced access to social benefits. As workers were unable to live securely and build a professional career, union movements reached international debate through cyberspace. Even going through periods of mass layoffs and changing cities, a call-centers' labor force began to act through social networks, combining strategies of struggle and "labor sabotage," as well as discussing their rights and sharing their experiences.

Julice Salvagni

Universidade Federal do Rio Grande do Sul - UFRGS julicesalvagni@gmail.com

Victória Mendoça da Silva Universidade Federal do Rio Grande do Sul - UFRGS vickmendoncas@gmail.com 